\title{
Life-history traits of the Kanzawa spider mite Tetranychus kanzawai (Acari: Tetranychidae)
}

\author{
Tetsuo GoтoH* and Koh GomI
}

Laboratory of Applied Entomology and Zoology, Faculty of Agriculture, Ibaraki University; Ami, Ibaraki 300-0393, Japan

(Received 5 July 2002; Accepted 2 September 2002)

\begin{abstract}
Life-history traits of the Kanzawa spider mite, Tetranychus kanzawai, were assessed and compared with those of the closely related species, T. parakanzawai. This was done by determining the intrinsic rates of natural increase, $r_{m}$, of three strains of T. kanzawai and one strain of T. parakanzawai, on leaf discs from each of the four host plants (collected plants) as well as one of suitable hosts for T. kanzawai, mulberry. The $r_{m}$-values of the three T. kanzawai strains varied largely from 0.187 /day to 0.283 /day, and the $r_{m}$ 's on the collected hosts (tea, hydrangea and Japanese pear) were 0.043-0.096/day lower than on mulberry. The $r_{m}$ of the T. parakanzawai strain was only 0.008/day lower on the collected plant (kudzu vine) than on mulberry. These results seem to suggest that tea, hydrangea and Japanese pear are poor-quality plants for T. kanzawai when compared to their performance on mulberry.
\end{abstract}

Key words: Tetranychus kanzawai; Tetranychus parakanzawai; intrinsic rate of natural increase; tea; host plant

\section{INTRODUCTION}

Performance of phytophagous insects and spider mites on different host plants is influenced by the nutritional value and defenses of the plants; important factors include secondary chemicals, leaf nutrition, leaf age and leaf surface structure (Gerson and Aronowitz, 1980; Jaenike, 1990; Wilson, 1994; Van Impe and Hance, 1993; Krips et al., 1998; Agrawal, 2000). When spider mites infest chemically defended or poor-quality plants, their intrinsic rate of natural increase $\left(r_{m}\right)$ should be low (Gould, 1979; Fry, 1989; Bruin et al., 1992; Krips et al., 1998; Agrawal, 2000). In the two-spotted spider mite, Tetranychus urticae Koch, for example, the initial $r_{m}$-value $(0.088 /$ day $)$ on a resistant gerbera cultivar was increased to 0.208 /day after they had been reared on this cultivar for five months, but it was still substantially lower than the $r_{m}$-value on a susceptible cultivar (0.242/day; Krips et al., 1998). Adaptation of mites to unsuitable host plants or novel host plants that are of poor quality is often accompanied by a reduction in fitness, even if the mites are polyphagous.

The Kanzawa spider mite, Tetranychus kanzawai Kishida, is an important pest threatening many agricultural crops and ornamental plants in Far
Eastern areas. The broad host range of T. kanzawai is due to the presence of host races: the ability to develop on tea, Camellia sinensis L., and hydrangea, Hydrangea macrophylla (Thunb.), containing harmful secondary chemicals for spider mites is regulated by a single dominant gene, ' $\mathrm{T}$ ' and ' $\mathrm{H}$ ', respectively (Gomi and Gotoh, 1996, 1997). These genes are thought to be involved in the chemical detoxification of harmful secondary chemicals, such as tannin in tea and hydrangenol in hydrangea (Dowd et al., 1983; Ujihara et al., 1995; Gomi and Gotoh, 1997; Gotoh and Gomi, 2000). Recently, T. parakanzawai Ehara, a sibling species of T. kanzawai, is found on the kudzu vine, Pueraria lobata (Willd.) (Ehara, 1999). The host range of this species overlaps considerably with that of $T$. kanzawai (Gomi and Gotoh, 1996), but T. parakanzawai never develops on tea or on hydrangea (Gotoh et al., 1999). For effective management of T. kanzawai, we need to know its ecological traits (population growth rate, etc.) on economically important plants. Most of the data obtained thus far are on easily grown host plants such as bean, while few are on crops such as grape (Kondo et al., 1987). The difference of the $r_{m}$-values among the infested plants affects the actual rates of population growth, that is, how rapid a population increases on

* To whom correspondence should be addressed at: E-mail: gotoh@mx.ibaraki.ac.jp 
an infested plant.

The objective of this study was to determine whether plants with known presence of harmful secondary chemicals affect the life-history traits of T. kanzawai. We compared the $r_{m}$-values of mites, reared on the host plants on which they had been collected in the field (collected host), to those of mites on mulberry, considered a suitable host of $T$. kanzawai (Gomi and Gotoh, 1996). In addition, the $r_{m}$-values of T. kanzawai were compared to those of T. parakanzawai, which could develop on neither tea nor hydrangea.

\section{MATERIALS AND METHODS}

The strains of T. kanzawai and T. parakanzawai used in this study are summarized in Table 1. These are the same strains that have been studied by Gomi and Gotoh $(1996,1997)$ and Gotoh et al. (1999). Each strain was maintained on leaf discs (ca. $25 \mathrm{~cm}^{2}$ ) of each host plant where the mites were collected (collected host), placed on a watersaturated polyurethane mat in a plastic dish $(9 \mathrm{~cm}$ in diam.) at $25^{\circ} \mathrm{C}$ and $16 \mathrm{~L}: 8 \mathrm{D}$. In winter, when hydrangea, Japanese pear (Pyrus pyrifolia (Burm.)) and kudzu vine (Pueraria lobata (Willd.)) leaves are not available because of complete defoliation, the strains collected from these hosts were reared on kidney bean (Phaseolus vulgaris L.). This is because all experiments were carried out between late July and late September in 1994.

To determine the developmental time, twenty females and five males from each stock culture were introduced onto a leaf disc and allowed to lay eggs for a 24-h period. Eggs laid were singly transferred and reared on a fresh leaf disc $\left(\mathrm{ca} .4 \mathrm{~cm}^{2}\right)$, and the developmental stages were recorded daily. When a female deutonymph emerged, one adult male obtained from a stock culture was introduced onto the leaf disc for mating and then removed $24 \mathrm{~h}$ after emergence of the adult female. The number of eggs laid by the females was recorded daily until they died. Plants examined in this study were tea, hydrangea, Japanese pear and kudzu vine as plants from which mite strains were initially collected, and mulberry as plant, known to suit T. kanzawai and T. parakanzawai (Gomi and Gotoh, 1996).

To assess the sex ratio ( $\%$ females) of the offspring, one teleiochrysalis female and one adult male were placed on a leaf disc for copulation, and the females were allowed to lay eggs for five days after the preoviposition period. The eggs obtained from each female were cultured to determine their hatchability, survival rate in immature stages and sex ratio of the emerging mites, after reaching adulthood. Plants examined were the same as mentioned above.

The intrinsic rate of natural increase, $r_{m}$, and other parameters were calculated according to the equations given by Birch (1948). Further details are described in Gotoh (1986). The parameters were calculated for strains reared on the collected plants and mulberry.

\section{RESULTS}

\section{Development}

The total developmental times from egg to adult in the four strains were 9.3-12.2 days and 8.6-11.6 days for females and males, respectively (Table 2). The tea strain reared on tea showed the longest developmental time, followed by the pear strain on pear. The developmental times of these two strains reared on the collected plants were significantly longer than those on mulberry $(p<0.05$, StudentNewman-Keuls test). For other strains, the times on the collected hosts were similar to those on mulberry $(p>0.05)$.

Hatchability ranged from 94.9 to $99.6 \%$ and sex ratio (proportion daughters) from 77.6 to $84.9 \%$ (Table 3). There appeared to be no significant differences between strains or host plants.

Table 1. Collection data of Tetranychus kanzawai $(\mathrm{Tk})$ and T. parakanzawai $(\mathrm{Tp})$ used in this study

\begin{tabular}{lllll}
\hline \multicolumn{1}{c}{ Strain (Species) } & \multicolumn{1}{c}{ Host plant } & City, Prefecture & Geographic coordinates & Date \\
\hline Tea (Tk) & Camellia sinensis & Kanaya, Shizuoka & $34^{\circ} 48^{\prime} \mathrm{N}-138^{\circ} 23^{\prime} \mathrm{E}$ & May 19, 1993 \\
Hydrangea (Tk) & Hydrangea macrophylla & Tsukuba, Ibaraki & $36^{\circ} 13^{\prime} \mathrm{N}-140^{\circ} 04^{\prime} \mathrm{E}$ & March 29, 1993 \\
Japanese pear (Tk) & Pyrus pyrifolia & Yachiyo, Chiba & $35^{\circ} 55^{\prime} \mathrm{N}-140^{\circ} 04^{\prime} \mathrm{E}$ & March 16, 1993 \\
Kudzu vine (Tp) & Pueraria lobata & Ami, Ibaraki & $36^{\circ} 00^{\prime} \mathrm{N}-140^{\circ} 11^{\prime} \mathrm{E}$ & June 5, 1993 \\
\hline
\end{tabular}




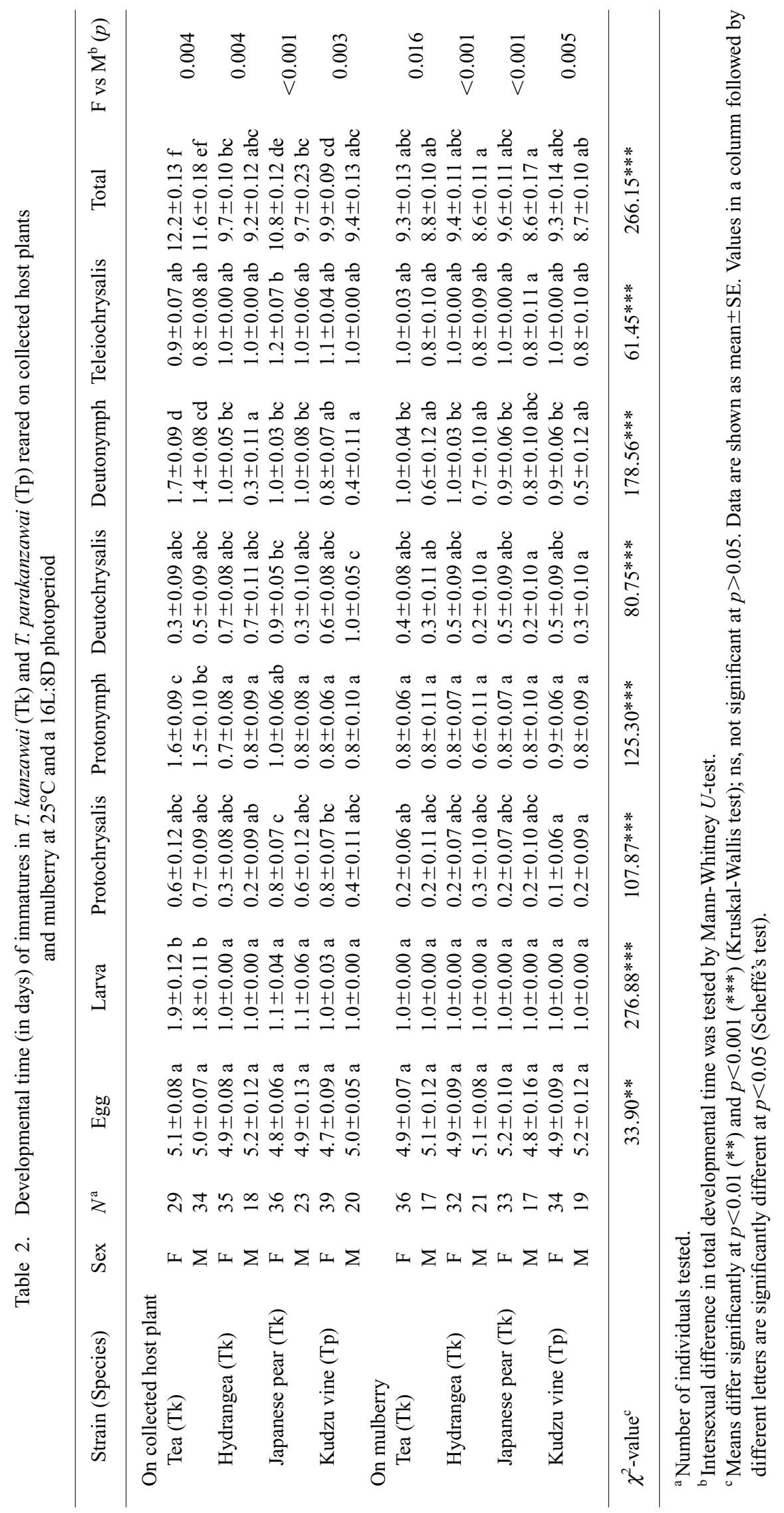


Table 3. Hatchability of eggs laid during the first 5 days of the oviposition period, survival rate of immature stages and the proportion of females reaching adulthood in T. kanzawai (Tk) and T. parakanzawai (Tp) reared on collected hosts and mulberry at $25^{\circ} \mathrm{C}$ and $16 \mathrm{~L}: 8 \mathrm{D}$ a photoperiod

\begin{tabular}{|c|c|c|c|c|c|}
\hline Strain & $N^{\mathrm{a}}$ & $\begin{array}{c}\text { No. of } \\
\text { eggs/female }\end{array}$ & Hatchability (\%) & $\begin{array}{l}\text { Survival rate in } \\
\text { immatures }(\%)\end{array}$ & $\begin{array}{l}\text { Proportion of } \\
\text { females }(\%)\end{array}$ \\
\hline \multicolumn{6}{|l|}{ On collected host plant } \\
\hline Tea (Tk) & 22 & $21.5 \pm 1.27 \mathrm{a}$ & $97.0 \pm 0.72 \mathrm{ab}$ & $99.0 \pm 0.45 \mathrm{a}$ & $77.6 \pm 1.49 \mathrm{a}$ \\
\hline Hydrangea (Tk) & 27 & $21.2 \pm 0.90 \mathrm{a}$ & $95.8 \pm 0.97 \mathrm{ab}$ & $96.7 \pm 0.87 \mathrm{a}$ & $83.9 \pm 1.04 \mathrm{~b}$ \\
\hline Japanese pear (Tk) & 14 & $37.4 \pm 1.28 \mathrm{~b}$ & $99.6 \pm 0.26 \mathrm{~b}$ & $98.0 \pm 0.57 \mathrm{a}$ & $84.9 \pm 0.82 \mathrm{~b}$ \\
\hline Kudzu vine (Tp) & 18 & $48.2 \pm 1.40 \mathrm{~d}$ & $98.4 \pm 0.36 \mathrm{ab}$ & $99.1 \pm 0.33 \mathrm{a}$ & $78.0 \pm 1.09 \mathrm{a}$ \\
\hline \multicolumn{6}{|l|}{ On mulberry } \\
\hline Tea $(\mathrm{Tk})$ & 23 & $41.0 \pm 1.19 \mathrm{bc}$ & $94.9 \pm 1.29 \mathrm{a}$ & $96.1 \pm 0.77 \mathrm{a}$ & $80.8 \pm 1.04 \mathrm{ab}$ \\
\hline Hydrangea (Tk) & 20 & $38.8 \pm 0.77 \mathrm{bc}$ & $98.3 \pm 0.52 \mathrm{ab}$ & $98.6 \pm 0.38 \mathrm{a}$ & $78.2 \pm 0.54 \mathrm{a}$ \\
\hline Japanese pear (Tk) & 28 & $44.5 \pm 1.14 \mathrm{~cd}$ & $99.5 \pm 0.30 \mathrm{~b}$ & $98.2 \pm 0.47 \mathrm{a}$ & $84.8 \pm 0.58 \mathrm{~b}$ \\
\hline Kudzu vine (Tp) & 34 & $43.9 \pm 1.22 \mathrm{bcd}$ & $99.2 \pm 0.36 \mathrm{~b}$ & $97.8 \pm 0.65 \mathrm{a}$ & $82.7 \pm 0.46 \mathrm{ab}$ \\
\hline$\chi^{2}$-value ${ }^{\mathrm{b}}$ & & $124.29 * * *$ & $28.28 * * *$ & $15.33^{*}$ & $57.16^{* * *}$ \\
\hline
\end{tabular}

\section{Oviposition}

Age at first oviposition in the tea strain on tea and the pear strain on pear was later than on mulberry $(p<0.05$, Scheffe's test; Table 4$)$. In the other two strains, first oviposition occurred at 11-12 days and did not differ between the collected hosts and mulberry.

Total number of eggs per female in the tea strain on tea and the hydrangea strain on hydrangea was significantly lower than on mulberry (Table 4). The number of eggs per female per day in the tea, hydrangea and pear strains was higher on mulberry than on the collected hosts $(p<0.05)$. Oviposition period and total adult longevity were almost as high on the collected host as on mulberry.

On the other hand, the total number of eggs laid in the kudzu vine strain of T. parakanzawai was significantly higher on the collected host than on mulberry. The number of eggs laid per female per day in the kudzu vine strain was the same for both the collected hosts and mulberry $(p>0.05)$. The oviposition period was significantly shorter on mulberry than on the original host $(p<0.05)$. Likewise, total adult longevity was shorter in the kudzu vine strain on mulberry.

Figure 1 shows $l_{x}$ (age-specific survival rate $\times$ egg hatchability), $m_{x}$ (age-specific oviposition rate $\times$ proportion of females) and $l_{x} m_{x}$ (the expected number of female offspring at age $x$ ) curves in $T$. kanzawai and T. parakanzawai at $25^{\circ} \mathrm{C}$. On the collected hosts, the daily egg production reached a peak of 4.2 eggs on day 16, 4.9 eggs on day 14, 6.3 eggs on day 17 and 12.0 eggs on day 14 in the tea, hydrangea, pear and kudzu vine strains, respectively. On mulberry, on the other hand, the oviposition rate peaked at 10.6 eggs on day $13,10.3$ eggs on day $15,10.6$ eggs on day 14 and 11.3 eggs on day 15 in the tea, hydrangea, pear and kudzu vine strains, respectively. Female adults started to die on the collected hosts on day 24, 21, 26 and 24 in the tea, hydrangea, pear and kudzu vine strains, respectively. On mulberry, survival of the female adults began to decrease on day 23, 24, 22 and 23 in the respective strains.

\section{Rate of population increase}

The net reproductive rate $\left(R_{0}\right)$, intrinsic rate of natural increase $\left(r_{m}\right.$, day $\left.^{-1}\right)$, mean generation time ( $T$, in days), finite rate of increase $(\lambda)$, and doubling time $(D)$ in the four strains are given in Table 5 . The $R_{0}$-values on the collected hosts were lower than those on mulberry except for the kudzu vine strain, whose $R_{0}$-value was higher on the collected plant than on mulberry. The $r_{m}$-and $\lambda$-values were higher on mulberry than on the collected hosts for all four strains. Mean generation times were higher on the collected plant than on mulberry, except the hydrangea strain showing similar values on the two 


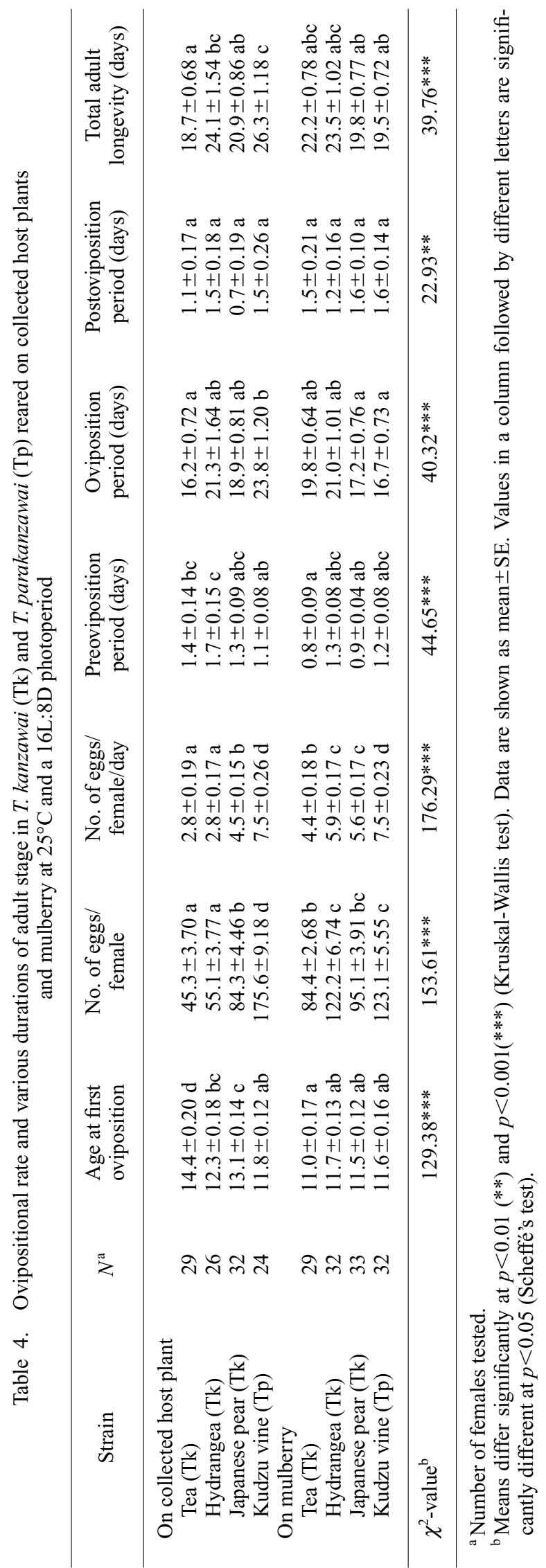

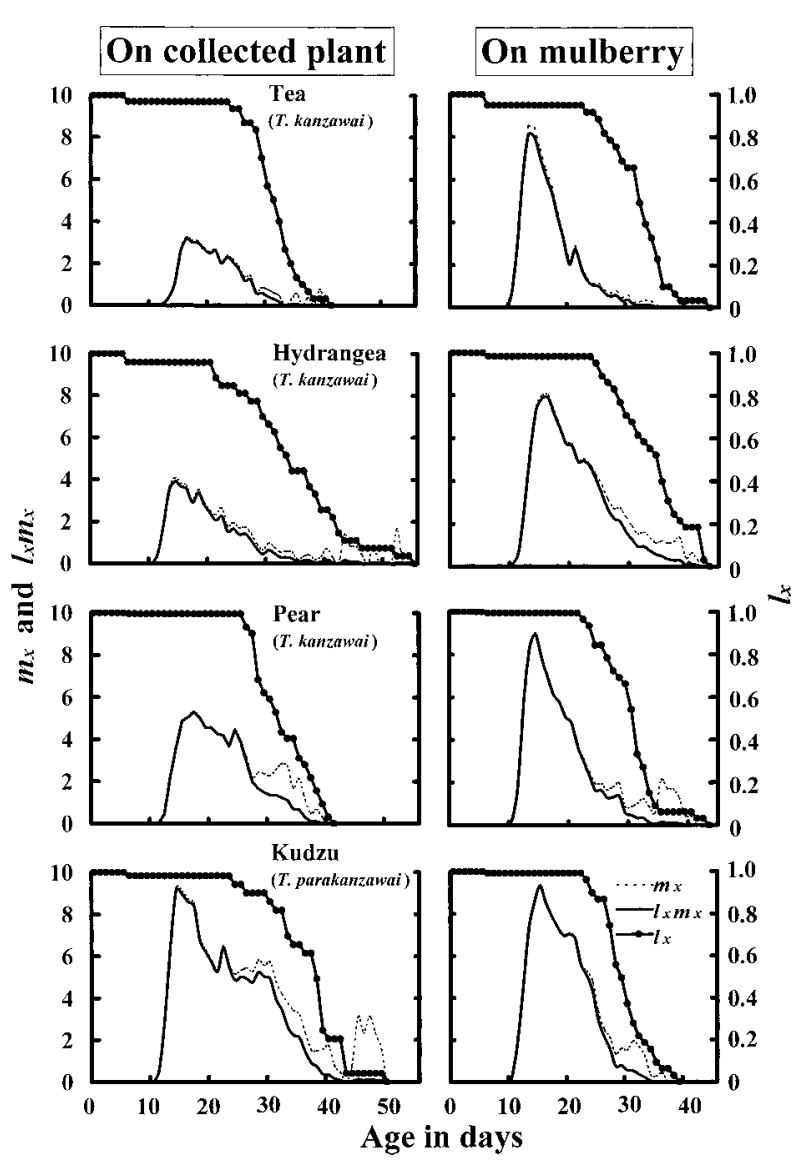

Fig. 1. The age-specific survival rate $\left(l_{x}\right)$, age-specific fecundity rate $\left(m_{x}\right)$ and $l_{x} m_{x}$ curves in $T$. kanzawai and $T$. parakanzawai strains at $25^{\circ} \mathrm{C}$ and $16 \mathrm{~L}: 8 \mathrm{D} . l_{x}=$ (proportion of females alive at age $x) \times($ egg hatchability $), m_{x}=($ age-specific oviposition $) \times($ proportion of females $)$.

plants. On the collected hosts, doubling times decreased in the order of tea $>$ hydrangea $>$ pear $>$ kudzu vine strains, but on mulberry they remained more or less the same.

\section{DISCUSSION}

The present study showed that some plants have significantly adverse effects on development and reproduction of T. kanzawai. Large differences in the $r_{m}$-values of $T$. kanzawai were found, ranging from $0.187 /$ day in the tea strain on tea to 0.283 /day in the tea and pear strains on mulberry. Although we used strains reared on their collected host plants for three months (May-July 1994) or one year (tea strain; May 1993-July 1994), the $r_{m}$-values on the collected hosts were 0.043-0.096/day lower than those on mulberry. It seems it is not only harmful secondary chemicals in tea and hydrangea leaves 
Table 5. Parameters related to potential rates of population increase in T. kanzawai (Tk) and T. parakanzawai (Tp) reared on collected host plant and mulberry at $25^{\circ} \mathrm{C}$ and $16 \mathrm{~L}: 8 \mathrm{D}$ photoperiod

\begin{tabular}{lcccccc}
\hline \multicolumn{1}{c}{ Strain } & $N^{\mathrm{a}}$ & $\begin{array}{c}\text { Net } \\
\text { reproductive } \\
\text { rate, } R_{0}\end{array}$ & $\begin{array}{c}\text { Intrinsic rate of } \\
\text { natural increase, } \\
r_{m} \text {, day }\end{array}$ & $\begin{array}{c}\text { Mean generation } \\
\text { time, } T \text {, in days }\end{array}$ & $\begin{array}{c}\text { Finite rate of } \\
\text { increase, } \lambda\end{array}$ & $\begin{array}{c}\text { Doubling } \\
\text { time, } D\end{array}$ \\
\hline On collected host plant & & & & & & \\
$\quad$ Tea (Tk) & 29 & 34.11 & 0.187 & 20.46 & 1.205 & 3.707 \\
$\quad$ Hydrangea (Tk) & 26 & 44.27 & 0.224 & 19.65 & 1.251 & 3.094 \\
$\quad$ Japanese pear (Tk) & 32 & 71.24 & 0.229 & 21.25 & 1.258 & 3.027 \\
$\quad$ Kudzu vine (Tp) & 24 & 134.80 & 0.276 & 22.17 & 1.318 & 2.511 \\
On mulberry & & & & & & \\
Tea (Tk) & 29 & 64.70 & 0.283 & 16.51 & 1.326 & 2.449 \\
Hydrangea (Tk) & 32 & 93.93 & 0.267 & 19.81 & 1.307 & 2.596 \\
Japanese pear (Tk) & 33 & 80.26 & 0.283 & 17.61 & 1.328 & 2.449 \\
Kudzu vine (Tp) & 32 & 101.01 & 0.284 & 18.44 & 1.329 & 2.441 \\
\hline
\end{tabular}

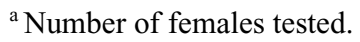

that affect life-history parameters of T. kanzawai, but also that Japanese pear is of poor quality to the mite. Nevertheless, for the tea strain reared on tea leaves during the subsequent one year or more after collection, the $r_{m}$-value remained $0.187 /$ day, which was still $0.096 /$ day lower than that on mulberry. This suggests that the initial $r_{m}$-value, which is examined just after collection, will be lower than this value. We need to clarify how the $r_{m}$-values change with the number of generations after collection.

Sabelis $(1985,1991)$ gives an extensive review of life-history parameters of tetranychid mites. For Tetranychus mites, he found the $r_{m}$-values to range from 0.200 to $0.336 /$ day at around $25^{\circ} \mathrm{C}$. The $r_{m}{ }^{-}$ values of $T$. kanzawai and T. parakanzawai fall within this range, except for the tea strain on tea $(0.187 /$ day $)$. The $r_{m}$ of the hydrangea strain on mulberry was comparable to the previously reported value (0.268/day) of T. kanzawai on bean (Kondo and Takafuji, 1985), but other strains on mulberry had slightly higher $r_{m}$-values than the hydrangea and bean strains. Similar examples of varying $r_{m}{ }^{-}$ values among plants are known in the citrus red mite, Panonychus citri (McGregor), Tetranychus pacificus McGregor and T. urticae. Two Tetranychus species displayed a lower $r_{m}$ when reared on cotton compared to bean (Takafuji and Chant, 1976; Carey and Bradley, 1982; Sabelis, 1991). Gerson and Aronowitz (1980) showed that the $r_{m}{ }^{-}$ values of T. urticae (called T. cinnabarinus (Boisduval) in that paper) reared on seven different plants varied from 0.091 (Algerian ivy) to 0.270 (bean). The $r_{m}$ of $P$. citri was lower on citrus leaf than on pear and peach leaves (Furuhashi and Nishino, 1979). These studies show that spider mites exhibit the capacity to adapt to unsuitable or poor-quality plants but the $r_{m}$-values remained at the lower level on them, although given enough time, the $r_{m}$ may grow to some extent. It seems likely that $T$. kanzawai is implicitly adapting to these plants, if we consider its propensity for rapid development of resistance to various kinds of acaricides (e.g., Goka, 1998).

The two parameters of paramount importance in determining the $r_{m}$-value are developmental time and ovipositional rate (Snell, 1978; Wrensch, 1985). For the $r_{m}$ of spider mites, changes in developmental time are more important than similar changes in ovipositional rate (Sabelis, 1985). In the present study, the tea strain on tea and the hydrangea strain on hydrangea showed similar ovipositional rates (Table 3), but developmental time in the tea strain was 2.5 days longer than that in the hydrangea strain (Table 2). As a result, the $r_{m}$-value in the former was 0.037 /day lower than that in the latter. Since the developmental time among strains was similar (except for the tea strain), the difference among $r_{m}$-values assessed on the collected host plants and mulberry is attributed to the difference in ovipositional rate. The hydrangea strain, for example, displayed a higher $r_{\mathrm{m}}$-value on mulberry than on hydrangea, because the peak ovipositional rate differed greatly: on mulberry it was 10.3 eggs on day 15 , whereas on hydrangea it was 4.9 eggs 
on day 14.

Rodriguez et al. (1983) showed that the density of T. urticae was higher on young soybean leaves than on old leaves. The tea strain on tea showed the lowest $r_{m}$-value in the present study. We used mature leaves of tea plant for rearing this strain, but we should test the $r_{m}$-value on young leaves, because the absolute $r_{m}$-value on tea may become higher than in this study, as shown in T. urticae. However, it is difficult to test this possibility, because leaf discs made of young leaves promptly deteriorated and could not maintain leaf quality throughout the experimental periods. The relationship between leaf age of tea and developmental performance of mites remains to be clarified.

The $r_{m}$-values of $T$. kanzawai differed significantly among the plants tested. This seems to be attributable to differences in the adaptation degrees to host-plant resistance and/or nutritional quality of the hosts. Hence, the $r_{m}$-values of economically important mites should be determined on the crop plants they attack, rather than on easily grown plants such as bean, especially when one's aim is to control these mites.

\section{ACKNOWLEDGEMENTS}

We are indebted to J. Bruin, University of Amsterdam, for invaluable comments, and to S. Yano, Kyoto University, for his kind suggestions.

\section{REFERENCES}

Agrawal, A. A. (2000) Host-range evolution: adaptation and trade-offs in fitness of mites on alternative hosts. Ecology 81: 500-508.

Birch, L. C. (1948) The intrinsic rate of natural increase of an insect population. J. Anim. Ecol. 17: 15-26.

Bruin, J., T. Gotoh, M. W. Sabelis, S. B. J. Menken and W. E. van Ginkel (1992) Host-race formation in the two-spotted spider mite (Tetranychus urticae). In Proceedings of the 8th International Symposium on Insect-Plant Relationships (S. B. J. Menken, J. H. Visser and P. Harrewijn eds.). Kluwer Academic Publishers, Dordrecht, pp. 203-204.

Carey, J. R. and J. W. Bradley (1982) Developmental rates, vital schedules, sex ratios, and life tables for Tetranychus urticae, T. turkestani and T. pacificus (Acarina: Tetranychidae) on cotton. Acarologia 23: 333-345.

Dowd, P. F., M. Smith and T. C. Sparks (1983) Detoxification of plant toxins by insects. Insect Biochem. 13: 453-468.

Ehara, S. (1999) Revision of the spider mite family Tetranychidae of Japan (Acari, Prostigmata). Species Diversity 4: 63-141.

Fry, J. D. (1989) Evolutionary adaptation to host plants in a laboratory population of the phytophagous mite Tetrany- chus urticae Koch. Oecologia 81: 559-565.

Furuhashi, K. and M. Nishino (1979) Reproductive capacity of citrus red mite, Panonychus citri McG. on three fruit trees. Bull. Shizuoka Fruit Tree Res. Stn. 15: 41-44 (in Japanese).

Gerson, U. and A. Aronowitz (1980) Feeding of the carmine spider mite on seven host plant species. Entomol. Exp. Appl. 28: 109-115.

Goka, K. (1998) Mode of inheritance of resistance to three new acaricides in the Kanzawa spider mite, Tetranychus kanzawai Kishida (Acari: Tetranychidae). Exp. Appl. Acarol. 22: 699-708.

Gomi, K. and T. Gotoh (1996) Host plant preference and genetic compatibility of the Kanzawa spider mite, Tetranychus kanzawai Kishida (Acari: Tetranychidae). Appl. Entomol. Zool. 31: 417-425.

Gomi, K. and T. Gotoh (1997) Genetic basis for host range in Tetranychus kanzawai Kishida (Acari: Tetranychidae). Appl. Entomol. Zool. 32: 638-641.

Gotoh, T. (1986) Life-history parameters of the hawthorn spider mite, Tetranychus viennensis Zacher (Acarina: Tetranychidae), on deciduous oak. Appl. Entomol. Zool. 21: 389-393.

Gotoh, T. and K. Gomi (2000) Population dynamics of Tetranychus kanzawai (Acari: Tetranychidae) on hydrangea. Exp. Appl. Acarol. 24: 337-350.

Gotoh, T., K. Gomi and T. Nagata (1999) Incompatibility and host plant differences among populations of Tetranychus kanzawai Kishida (Acari: Tetranychidae). Appl. Entomol. Zool. 34: 551-561.

Gould, F. (1979) Resistance of cucumber varieties to Tetranychus urticae: genetic and environmental determinants. J. Econ. Entomol. 71: 680-683.

Jaenike, J. (1990) Host specialization in phytophagous insects. Annu. Rev. Ecol. Syst. 21: 243-273.

Kondo, A., T. Hiramatsu and T. Henmi (1987) Life history parameters of grape- and bean-adapted populations of the Kanzawa spider mite, Tetranychus kanzawai Kishida (Acarina: Tetranychidae) on grape and bean. Jpn. J. Appl. Entomol. Zool. 31: 291-296 (in Japanese with English summary).

Kondo, A. and A. Takafuji (1985) Resource utilization pattern of two species of tetranychid mites (Acarina: Tetranychidae). Res. Popul. Ecol. 27: 145-157.

Krips, O. E., A. Witul, P. E. L. Willems and M. Dicke (1998) Intrinsic rate of population increase of the spider mite Tetranychus urticae on the ornamental crop gerbera: intraspecific variation in host plant and herbivore. Entomol. Exp. Appl. 89: 159-168.

Rodriguez, J. G., D. A. Reicosky and C. G. Patterson (1983) Soybean and mite interaction: effects of cultivar and plant growth stage. J. Kansas Entomol. Soc. 56: 320-326.

Sabelis, M. W. (1985) Reproductive strategies. In Spider Mites. Their Biology, Natural Enemies and Control, 1A (W. Helle and M. W. Sabelis eds.). Elsevier, Amsterdam, pp. 265-278.

Sabelis, M. W. (1991) Life-history evolution of spider mites. In The Acari. Reproduction, Development and Life-History Strategies (R. Schuster and P. W. Murphy eds.). 
Chapman \& Hall, London, pp. 23-49.

Snell, T. W. (1978) Fecundity, developmental time, and population growth rate. Oecologia 32: 119-125.

Takafuji, A. and D. A. Chant (1976) Comparative studies of two species of predaceous phytoseiid mites (Acarina: Phytoseiidae), with special reference to their responses to the density of their prey. Res. Popul. Ecol. 17: 255-310.

Ujihara, M., M. Shinozaki and M. Kato (1995) Accumulation of phyllodulcin in sweet leaf plants of Hydrangea serrata and its neutrality in the defense against a specialist leafmining herbivore. Res. Popul. Ecol. 37: 249-257.

Van Impe, G. and T. Hance (1993) A technique for testing varietal susceptibility to the mite Tetranychus urticae Koch (Acari: Tetranychidae). Application to bean, cucumber, tomato and strawberry. Agronomie 13: 739749 (in French).

Wilson, L. J. (1994) Plant-quality effect on life-history parameters of the twospotted spider mite (Acari: Tetranychidae) on cotton. J. Econ. Entomol. 87: 1665-1673.

Wrensch, D. L. (1985) Reproductive parameters. In Spider Mites. Their Biology, Natural Enemies and Control, 1A (W. Helle and M. W. Sabelis eds.). Elsevier, Amsterdam, pp. 165-170. 